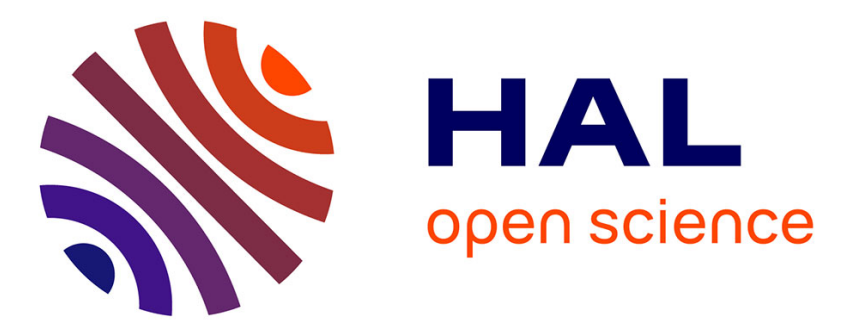

\title{
Effect of thymol and resveratrol administered with candy or syrup on the development of Nosema ceranae and on the longevity of honeybees (Apis mellifera L.) in laboratory conditions
}

Cecilia Costa, Marco Lodesani, Lara Maistrello

\section{To cite this version:}

Cecilia Costa, Marco Lodesani, Lara Maistrello. Effect of thymol and resveratrol administered with candy or syrup on the development of Nosema ceranae and on the longevity of honeybees (Apis mellifera L.) in laboratory conditions. Apidologie, 2010, 41 (2), 10.1051/apido/2009070 . hal-00892060

\author{
HAL Id: hal-00892060 \\ https://hal.science/hal-00892060
}

Submitted on 1 Jan 2010

HAL is a multi-disciplinary open access archive for the deposit and dissemination of scientific research documents, whether they are published or not. The documents may come from teaching and research institutions in France or abroad, or from public or private research centers.
L'archive ouverte pluridisciplinaire HAL, est destinée au dépôt et à la diffusion de documents scientifiques de niveau recherche, publiés ou non, émanant des établissements d'enseignement et de recherche français ou étrangers, des laboratoires publics ou privés. 


\title{
Effect of thymol and resveratrol administered with candy or syrup on the development of Nosema ceranae and on the longevity of honeybees (Apis mellifera $\mathrm{L}$.) in laboratory conditions*
}

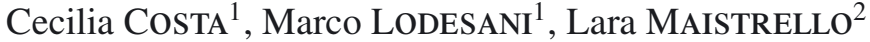 \\ ${ }^{1}$ Consiglio per la Ricerca e la sperimentazione in Agricoltura, Unità di Ricerca di Apicoltura e Bachicoltura \\ (CRA-API), via di Saliceto 80, 40128 Bologna, Italy \\ ${ }^{2}$ Dipartimento di Scienze Agrarie e degli Alimenti, Università di Modena e Reggio Emilia, via G. Amendola 2, \\ Area San Lazzaro - Pad. Besta, 42100 Reggio Emilia, Italy
}

Received 20 March 2009 - Revised 6 July 2009 - Accepted 16 July 2009

\begin{abstract}
The aim of this study was to evaluate the effect of thymol and resveratrol administered in two different formulation modes (candy and syrup) on the development of Nosema ceranae and on the longevity of honey bees. Emerging bees from a nosema-free apiary were individually infected with $1 \mu \mathrm{L}$ of sucrose syrup containing 18000 spores of $N$. ceranae, placed in cages, and kept in an incubator at $33{ }^{\circ} \mathrm{C}$ and $65 \%$ $\mathrm{RH}$. The experimental groups were fed candy or syrup prepared with thymol $(100 \mathrm{ppm})$ or resveratrol $(10 \mathrm{ppm})$. Infection levels were monitored over a 25 day period by removal and dissection of two live bees per cage. On day 25, post-infection bees fed with thymol syrup had significantly lower levels of infection ( $60 \pm 9$ million spores/bee) compared to control bees (138 \pm 7 million spores/bee). Bees fed with thymol or resveratrol syrup lived significantly longer ( 23 and 25 days, respectively) than bees fed with control syrup (20 days). Thymol treated syrup appears to be promising in the control of nosema infection.
\end{abstract}

\section{Nosema / microsporidian / honey bee / thymol / resveratrol}

\section{INTRODUCTION}

Nosemosis in European honey bees (Apis mellifera L.) was traditionally known to be caused by the microsporidian Nosema apis Zander, a fungus. In recent years, however, Nosema ceranae Fries, originally identified on the Asian honey bee Apis cerana (Fries et al., 1996), has been reported to infect European honey bees worldwide (Higes et al., 2006; Chauzat et al., 2007; Huang et al., 2008; Chen et al., 2008) and may be replacing $N$. apis (Klee et al., 2007). Disease caused by $N$. apis has always been common throughout the beekeeping world (Matheson, 1996) with reported negative impact on hive productivity

Corresponding author: L. Maistrello,

lara.maistrello@unimore.it

* Manuscript editor: David Tarpy and colony survival over the winter (Fries et al., 1984; Goodwin et al., 1990). N. ceranae causes similar symptoms (Higes et al., 2006) but, according to some authors, may represent a more serious threat to apiculture than $N$. apis and be responsible for the sudden collapses of bee colonies reported in recent years in many countries (Paxton et al., 2007; Higes et al., 2008, 2009). It has recently been shown that bees infected with $N$. ceranae have a shortened life span due to energetic stress and that their feeding behaviour is also affected (Mayack and Naug, 2009; Naug and Gibbs, 2009).

The only known effective substance for the control of nosemosis is the antibiotic fumagillin (Moffet et al., 1969), which inhibits the development of both $N$. apis (Katznelson and Jamieson, 1952; Liu, 1973) and N. ceranae (Williams et al., 2008a). The use of antibiotics 
for the treatment of diseased beehives, however, is forbidden in most European countries. Even where treatments with fumagillin are possible, its use poses the problem of reoccurrence of the disease (Higes et al., 2008) as only the vegetative forms of the parasite are killed (MacDonald, 1978; Szabo and Heikel, 1987; Wyborn and McCutcheon, 1987) and the risk of antibiotic residues in honey is a growing concern to the current honey market (Martin, 2003). The possibility of controlling nosema with ecologically-friendly products is therefore much desired throughout the beekeeping world.

In a previous experiment, in which we evaluated the potential of several natural compounds in the inhibition of nosema development in caged bees (Maistrello et al., 2008), both thymol (3-hydroxy-p-cymene) and resveratrol (3,4',5-trihydroxystilbene), administered with sugar candy proved promising. Also in that experiment, no differences were noticed in the appetibility of the treated candies compared to control candies or in the mortality of non-inoculated bees fed with the different substances.

Thymol is well known by beekeepers due its suppressive effects against the parasitic mite Varroa destructor (Chiesa, 1991) and has been shown not to be toxic to honey bees at the concentrations used in the present work, either by physical contact (Imdorf et al., 1995) or per os (Detzel and Wink, 1993; Ebert et al., 2007). Furthermore, thymol has been shown to suppress development of Nosema vespula in Helicoverpa armigera caterpillars (Rice, 2001) and to inhibit the growth of pathogenic bacteria and fungi, such as Salmonella typhimurium, Staphylococcus aureus (Juven et al., 1994), Aspergillus flavus (Mahmoud, 1999) and Cryptococcus neoformans (Viollon and Chaumont, 1994). Recently, thymol is being investigated as means of alternative chemical control for several plant pathogenic fungi (Svircev et al., 2007; Dambolena et al., 2008) as well as human oral bacteria (Bennis et al., 2004). Due to its low toxicity (Lenga, 1988) and low residuality in honey (Bogdanov et al., 1998), thymol is authorised for use in varroa control in organic beekeeping, according to EU Regulation 834/2007 on organic produc- tion (EC, 2007). Resveratrol is a natural phytoalexin, produced by some plants in response to infections caused by phytopathogenic microorganisms, and is known for its anti-cancer and anti-inflammatory effects in mammals (Luna et al., 2009; Pallas et al., 2009; Dann et al., 2009; Park et al., 2009). It has been shown that resveratrol can inhibit the development of the microsporidian Encephalitazoon cunicoli in in vitro experiments (Leiro et al., 2004).

Considering that in the spring colonies are usually fed with syrup rather than candy, in this experiment our aim was to assess whether the potential nosema control substances, thymol and resveratrol, were equally effective when administered with syrup compared to candy, in terms of impact on nosema infection and on the longevity of infected bees.

\section{MATERIALS AND METHODS}

\subsection{Experimental design}

Treated candy or syrup were administered to honey bee workers artificially infected with $N$. ceranae, and thereafter kept in small wooden, glasssided cages measuring $10 \times 10 \times 20 \mathrm{~cm}$, provided with a small frame and foundation, and gravity feeders and/or feeding dishes. Each cage contained approximately 30 bees and was incubated at $33{ }^{\circ} \mathrm{C}$ and $65 \% \mathrm{RH}$ in the dark.

Each treatment was replicated four times, thus yielding a total of 24 cages: 2 administrations (syrup and candy) $\times 3$ groups $(2$ active ingredients (a.i.) +1 control) $\times 4$ replicates. The control cages consisted in infected bees fed with untreated syrup and candy.

\subsection{Spore suspension}

Bees infected with Nosema ceranae were obtained from an apiary located in the North-East of Italy where nosema disease is endemic. These bees were crushed in saline solution, filtered through nylon mesh, and the resulting suspension further purified by two rounds of centrifugation $(800 \mathrm{~g}$, $6 \mathrm{~min})$ and re-suspension in saline solution. The concentration of $N$. ceranae spores was then determined by haemacytometer count (Cantwell, 1970). 
After another centrifugation, the spores were resuspended in the quantity of $50 \% \mathrm{w} / \mathrm{v}$ sucrose solution necessary to yield a final concentration of 18000 spores per $\mu \mathrm{L}$. The obtained spore suspension was used immediately after preparation. An aliquot of the spore suspension was used for molecular species identification (Martìn-Hernández et al., 2007).

\subsection{Bees}

Newly emerged honey bees (Apis mellifera L., presumably $A$. $m$. ligustica) were obtained from a colony in the CRA-API apiary in Reggio Emilia, after having analysed a sample of bees from the outer frames of the hive to verify absence of nosema spores. Combs with emerging bees and capped cells close to emergence were brought into the laboratory and incubated at $33{ }^{\circ} \mathrm{C}$ and $65 \% \mathrm{RH}$, in the dark, for 6 hours. Newly emerged bees were manually collected and individually fed with $1 \mu \mathrm{L}$ of the inoculated sucrose syrup suspension before being placed in the cages.

\subsection{Treated feed: syrup and candy}

Two different modes of administration of the natural compounds were tested: syrup and candy. A $50 \% \mathrm{w} / \mathrm{v}$ sucrose solution was used to prepare the treated syrups and bee candy was prepared by mixing icing sugar $(85 \%)$, honey produced in our apiary $(10 \%)$, and water $(5 \%)$. Ethanol $(3,2 \mu \mathrm{L} / \mathrm{g})$ was used to aid solubility of both thymol and resveratrol, and added to the control syrup and candy. Previous experiments had shown that, at the above concentration, the presence of ethanol had not affected either food consumption or bee mortality. The concentrations of the a.i. in the syrup and candy were $0.1 \mathrm{mg} / \mathrm{g}$ of thymol (thymol minimum $99.5 \%$, Sigma) and $0.01 \mathrm{mg} / \mathrm{g}$ of resveratrol (resveratrol approx. $99 \%$ GC, Sigma), which were in the same range of the concentrations that had appeared to be the most promising in the previous experiment. The syrup was administered to the bees via gravity feeders fitted into each cage, initially containing $4 \mathrm{~mL}$ syrup, which was replaced every 3 days (an up-turned $5 \mathrm{~mL}$ plastic syringe from which the point had been cut off, placed in the cage in such a way that the bees could easily access the nozzle). The candy contained in a $3 \mathrm{~cm}$ diameter Petri dish $(9 \mathrm{~g})$ was positioned upside-down on a $1 \mathrm{~cm}$ diameter hole on top of the cage. In the cages where bees were fed with candy, a gravity feeder containing water was also fitted. The treated feed was administered to the cages immediately after inoculation. The intake of syrup and candy was recorded every 3 days.

\subsection{Monitoring the infection}

Two live bees were removed from each cage at 4 time-points: 8, 13, 19, and 25 days after inoculation, to monitor the development of the infection. These days were chosen as the intervals between them correspond to the average length of a $N$. apis development cycle (Fries, 1993). The midgut and rectum of each bee was removed and kept with $1 \mathrm{~mL}$ saline solution at $-20{ }^{\circ} \mathrm{C}$ until the spore count was performed (Cantwell, 1970). In the cages where all the bees had died by the 25th day the evaluation was carried out on the most recently dead bees.

Starting from the second day after inoculation the number of dead bees in each cage was recorded every $2-3$ days.

\subsection{Statistical analysis}

Daily feed intake of bees fed with the differently treated candies or syrups was compared by means of a two-way analysis of variance (ANOVA), to verify the effect of the two formulations (syrup and candy) and of the treatments (thymol, resveratrol, and control).

For the calculation of survival times, the live bees collected for monitoring the infection at 8,13 , 19 , and 25 days were considered as censored data. For each differently fed group (thymol, resveratrol, control, administered via syrup and candy), a life table was calculated (pooling the data for each group after having individually verified that there were no statistical differences among the life tables of each individual cage of a group). For each of the six groups median survival times (the survival time at which the cumulative survival function is equal to $0.5)$ were obtained. Paired comparisons were then carried out with log rank test.

Considering the development of the infection, the mean spore load data of the collected live bees was log-transformed before analysis due to the skewed distribution.

Statistical analyses examined the differences among the six feeding groups in the four sampling dates. Comparisons of spore number in honey bee 


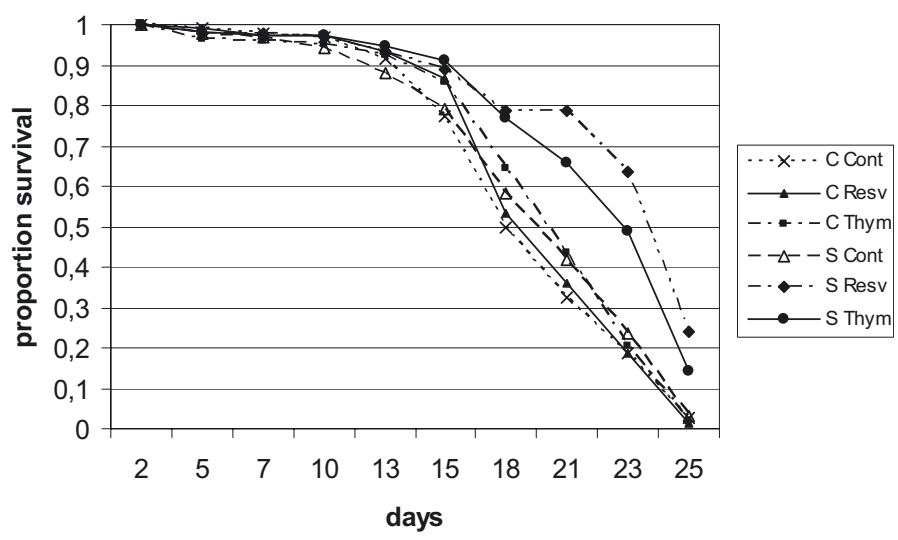

Figure 1. Survival curves of the differently fed groups (C Cont: candy control; C Resv: candy resveratrol; C Thym: candy thymol; S Cont: syrup control; S Resv: syrup resveratrol; S Thym: syrup thymol).

samples collected at each sampling date from the different feeding groups were made using KruskalWallis nonparametric test. Mann-Whitney U test was used for the two-samples comparison. A significance level of $\alpha=0.05$ was used to define statistical differences. A meta-analysis using standardized effect size (Hedges' $g$ ) followed by two-tailed T-test to obtain the probability value for mean differences was used to confirm significance of the results. All reported analyses were carried out using StatisticaStatSoft v. 7.1.

\section{RESULTS}

Molecular analysis of all the samples showed that spores used in the experiment belonged to $N$. ceranae.

\subsection{Feed intake}

Bees fed with syrups had a significantly higher $(F=62.45$, d.f. $=1,14, P<0.0001)$ average feed intake than bees fed with candy ( syrup $=69.15 \pm 3.65 \mathrm{mg} /$ bee $/$ day and candy $=$ $32.23 \pm 1.67 \mathrm{mg} /$ bee/day). No significant differences were observed in intake of candies or syrups containing different a.i. compared to controls (considering the factor treatment: $F=0.59$, d.f. $=2,14, P=0.57$ ) or when considering the interaction between the two factors, treatment and formulation $(F=0.05$, d.f. $=2,14, P=0.95)$.

\subsection{Bee survival}

For each of the six groups the survival curves fitted the Gompertz distribution. Results from survival analysis (Fig. 1) showed that 13 days after the beginning of the experiment, about $90 \%$ of the bees were still alive in all groups, independently from the kind of formulation or a.i. During the following days, differences among treatments became apparent, as the bees fed with thymol and resveratrol treated syrup lived significantly longer than bees fed with control syrup and with treated and control candy (Tab. I). No differences were detected in the survival of bees fed with the two a.i. within each formulation mode (Tab. I). These differences were significant even after Bonferroni adjustement.

\subsection{Development of infection}

Spore loads measured on sampled bees on the 1 st time point $(8 \mathrm{~d})$ were not significantly different and were very similar in all groups (range 1.32-1.99 $\times 10^{6}$ spores/bee), proving that individual inoculation was successful in providing an equal initial infection level (Tab. II). Development of the parasite was evident by the 2 nd time point (13 d) when differences among the groups started to appear, although not statistically significant 
Table I. Results of log-rank tests performed to compare survival times from different experimental groups. Numbers in brackets below each group name represent median survival times (days) obtained from the related survival function analysis. $\mathrm{C}=$ candy, $\mathrm{S}=$ syrup, Cont $=$ control, Resv $=$ resveratrol, Thym $=$ thymol. Significant comparisons are highlighted in bold.

\begin{tabular}{lllllll}
\hline & $\begin{array}{l}\text { C Cont } \\
(18)\end{array}$ & $\begin{array}{l}\text { C Resv } \\
(19)\end{array}$ & $\begin{array}{l}\text { C Thym } \\
(20)\end{array}$ & $\begin{array}{l}\text { S Cont } \\
(20)\end{array}$ & $\begin{array}{l}\text { S Resv } \\
(25)\end{array}$ & $\begin{array}{l}\text { S Thym } \\
(23)\end{array}$ \\
\hline C Cont & - & $\mathrm{Z}=0.4 ;$ & $\mathrm{Z}=1.1 ;$ & $\mathrm{Z}=1.2 ;$ & $\mathbf{Z = 6 . 4 ;}$ & $\mathbf{Z}=\mathbf{5 . 1} ;$ \\
& & $P=0.68$ & $P=0.26$ & $P=0.30$ & $\boldsymbol{P}<\mathbf{0 . 0 0 0 1}$ & $\boldsymbol{P}<\mathbf{0 . 0 0 0 1}$ \\
C Resv & - & - & $\mathrm{Z}=0.7 ;$ & $\mathrm{Z}=0.7 ;$ & $\mathbf{Z}=\mathbf{6 . 4} ;$ & $\mathbf{Z}=\mathbf{5 . 0} ;$ \\
& & & $P=0.47$ & $P=0.46$ & $\boldsymbol{P}<\mathbf{0 . 0 0 0 1}$ & $\boldsymbol{P}<\mathbf{0 . 0 0 0 1}$ \\
C Thym & - & - & - & $\mathrm{Z}=0.1 ;$ & $\boldsymbol{Z}=\mathbf{5 . 8} ;$ & $\boldsymbol{Z}=\mathbf{4 . 6}$ \\
& & & & $P=0.92$ & $\boldsymbol{P}<\mathbf{0 . 0 0 0 1}$ & $\boldsymbol{P}<\mathbf{0 . 0 0 0 1}$ \\
S Cont & - & - & - & - & $\mathbf{Z}=\mathbf{5 . 7} ;$ & $\mathbf{Z}=\mathbf{4 . 3} ;$ \\
& & & & & $P<\mathbf{0 . 0 0 0 1}$ & $\boldsymbol{P}<\mathbf{0 . 0 0 0 1}$ \\
S Resv & - & - & - & - & - & $Z$ \\
& & & & & & $P=0.07$ \\
\hline
\end{tabular}

Table II. Mean number of spores per bee $\left(\times 10^{6}\right) \pm \mathrm{SE}$ in honey bees collected at different sampling dates (d) from each feeding group (4 cages per group, 2 bees per cage). $\mathrm{C}=$ candy, $\mathrm{S}=$ syrup. For each formulation mode (candy or syrup), same letters after mean values $\pm \mathrm{SE}$ at the end of each column, indicate that values are not significantly different at $P<0.05$ level after Mann-Whitney $\mathrm{U}$ test.

\begin{tabular}{lllll}
\hline & $8 \mathrm{~d}$ & $13 \mathrm{~d}$ & $19 \mathrm{~d}$ & $25 \mathrm{~d}$ \\
\hline C Cont & $1.5 \pm 0.5 \mathrm{a}$ & $68.7 \pm 4.1 \mathrm{a}$ & $112.0 \pm 8.2 \mathrm{a}$ & $138.3 \pm 6.7 \mathrm{a}$ \\
C Resv & $1.3 \pm 0.7 \mathrm{a}$ & $32.5 \pm 9.1 \mathrm{a}$ & $69.2 \pm 11.2 \mathrm{a}$ & $98.7 \pm 24.3 \mathrm{ab}$ \\
C Thym & $1.7 \pm 0.7 \mathrm{a}$ & $53.1 \pm 8.1 \mathrm{a}$ & $93.0 \pm 18.5 \mathrm{a}$ & $60.5 \pm 17.8 \mathrm{~b}$ \\
\hline S Cont & $2.0 \pm 0.4 \mathrm{a}$ & $61.4 \pm 6.7 \mathrm{a}$ & $107.5 \pm 9.4 \mathrm{a}$ & $118.1 \pm 15.8 \mathrm{a}$ \\
S Resv & $1.3 \pm 0.3 \mathrm{a}$ & $51.2 \pm 7.4 \mathrm{a}$ & $80.6 \pm 4.3 \mathrm{a}$ & $126.2 \pm 1.2 \mathrm{a}$ \\
S Thym & $1.7 \pm 0.5 \mathrm{a}$ & $46.2 \pm 5.4 \mathrm{a}$ & $56.4 \pm 18.3 \mathrm{a}$ & $60.2 \pm 9.2 \mathrm{~b}$ \\
\hline
\end{tabular}

and limited to a $2 \times$ factor. By the 3 rd time point $(19 \mathrm{~d})$, differences among groups increased, although not significantly: the control groups reached infection levels higher than $100 \times 10^{6}$ spores/bee, while bees fed with the treated formulations had lower spore loads. Differences among the groups were significant $\left(\chi^{2}=11.63 ; P=0.040\right)$ in the last time point (25 d), when bees fed with thymol syrup or candy had the lowest level of spores.

Within the syrup formulation group on day 25 , thymol fed bees contained significantly fewer spores than both resveratrol $(\mathrm{U}=$ $0 ; P=0.034)$ and control $(\mathrm{U}=0 ; P=0.021)$ bees. Within the candy formulation group, the number of spores in the bees fed with thymol candy was statistically lower than the control group ( $\mathrm{U}=0 ; P=0.034)$ and not sig- nificantly different from the resveratrol group ( $\mathrm{U}=3 ; P=0.289)$, which was not different from control $(\mathrm{U}=1 ; P=0.127)$. These results were confirmed by the comparisons of the standardized effect sizes (Tab. III). In crosscomparisons between formulations only thymol syrup versus control candy was significant $(\mathrm{U}=0 ; P=0.034)$.

In bees fed with thymol, development of infection was markedly slower than in the other groups: the increase of infection between the 3rd and 4th time points was the lowest (only $6 \%$ increase in bees fed with thymol syrup), and in thymol candy even a decrease of infection was observed $(-35 \%)$. By the end of the experiment, control candy and thymol syrup had respectively the highest and lowest levels of infection (Tab. II). 
Table III. Standardized effect size of differences (Hedges' $g$ with 95\% confidence intervals and probability value) between number of spores per bee $\left(\times 10^{6}\right)$ in honey bees belonging to different experimental groups ( 2 bees per group collected 25 days p.i.). $\mathrm{C}=$ candy, $\mathrm{S}=$ syrup, $\mathrm{Cont}=$ control, $\mathrm{Resv}=$ resveratrol, Thym $=$ thymol. Significant comparisons are highlighted in bold.

\begin{tabular}{|c|c|c|c|c|}
\hline & C Resv & C Thym & S Resv & S Thym \\
\hline $\begin{array}{l}\text { C Cont } \\
\text { C Resv }\end{array}$ & $\begin{array}{l}\mathrm{g}=2.43 \\
(-0.50-0.96) \\
P=0.17 \\
-\end{array}$ & $\begin{array}{l}\mathbf{g}=\mathbf{4 . 3 7} \\
(\mathbf{0 . 6 6 - 2 . 5 1 )} \\
P=\mathbf{0 . 0 1} \\
\mathrm{g}=2.22 ; \\
(-0.66-0.78) ; \\
P=0.25\end{array}$ & & \\
\hline $\begin{array}{l}\text { S Cont } \\
\text { S Resv }\end{array}$ & & & $\begin{array}{l}\mathrm{g}=1.71 \\
(-1.08-0.31) \\
P=0.63 \\
-\end{array}$ & $\begin{array}{l}\mathrm{g}=3.63 ; \\
(0.26-1.95) ; \\
P=0.02 \\
\mathrm{~g}=6.92 ; \\
(1.82-4.37) ; \\
P=0.00\end{array}$ \\
\hline
\end{tabular}

\section{DISCUSSION}

From this experiment it emerges that feed intake did not differ according to treatment of feed with different a.i., in agreement with findings from a previous experiment (Maistrello et al., 2008) in which thymol and resveratrol treated candies were used. In addition to confirming lack of difference in candy intake, here we showed that intake of syrup also did not differ according to treatment. However, intake was significantly different on the basis of formulation, with syrup being consumed twice as much as candy. This was expected, as the bees fed with candy also had ad libitum access to water. It must therefore be underlined that although the concentrations of the a.i. were the same, the actual dose of a.i. differed according to a 2 -fold factor in the 2 formulation modes.

Thymol, administered either via syrup or via candy, was clearly able to reduce development of $N$. ceranae in the midgut, as deduced by the lower spore counts compared to the control groups observed from the second time point $(13 \mathrm{~d})$ until the last $(25 \mathrm{~d})$ when spore loads were halved. It has been suggested that thymol affects both bacteria (Shapiro and Guggenheim, 1995) and fungi (Svircev et al., 2007; Dambolena et al., 2008) by causing perforation of plasma membrane leading to extra-cellular leakage, and in the case of yeast also by disrupting the cell wall
(Bennis et al., 2004). The average daily dose of thymol assumed by each bee with candy was $3.2 \times 10^{-3} \mathrm{mg}$ : this amount appeared to be sufficient to partially inhibit development of the infection. The daily dose assumed with syrup was twice as much but a further reduction of infection was not observed, suggesting absence of dose-dependent effect and that a threshold level was reached with the dose administered via candy. In our previous experiment (Maistrello et al., 2008), however, a slightly higher concentration of thymol $(0.12 \mathrm{mg} / \mathrm{g})$ administered in candy had led to a greater inhibition of nosema development than the one observed in the current trial. Further research is needed to clarify this aspect.

The presence of thymol or resveratrol in syrup caused nosema-infected bees to live significantly longer than control bees or bees fed with treated candies. In the case of thymol, higher survival might be related to the lower spore load, whereas in the case of resveratrol (where spore loads were not different from control bees), higher survival might be explained by specific life-prolonging antioxidant properties of this substance. It has been shown that resveratrol can prolong the lifespan of the invertebrates Caenorhabditis elegans and Drosophila melanogaster (Wood et al., 2004) and of the short-lived fish Nothobranchius furzeri by activating enzymes that promote cell survival (Valenzano et al., 2006). 
In the budding yeast Saccharomyces cerevisiae, resveratrol increases DNA stability and extends cell lifespan by $70 \%$ (Howitz et al., 2003). Therefore, the higher survival of bees fed with resveratrol in the syrup formulation mode compared to candy could be explained by the differences in the average daily intake, twice as much in the case of syrup. Indeed, these data confirm results from our previous work (Maistrello et al., 2008) in which bees fed with resveratrol candy survived longer than control bees notwithstanding the same infection level.

The median survival time observed in bees fed with non-treated formulations was higher than that observed by Higes et al. (2007) in an artificial infection experiment, where total mortality on day 8 post-infection was $100 \%$. However, the infection dose used in that experiment was almost 10 -fold than the one used in the present trial (125000 vs. 18000 spores/bee respectively). Median survival times in $A$. $m$. ligustica bees inoculated with $10000 \mathrm{~N}$. apis spores each and fed with sucrose syrup had been observed to be 22 days (Malone and Stefanovic, 1999), similar to the median survival time observed in the control bees fed with syrup in the present experiment (20 days, bees initially inoculated with 18000 $N$. ceranae spores each). Another possibility for differences between results of this study and those of Higes et al. (2007) is variability in $N$. ceranae virulence. It has been shown that different haplotypes of Nosema spp. in honey bees exist (Williams et al., 2008b), although it is not known whether there is a corresponding difference in virulence. However, in bumble bees, Tay et al. (2005) showed that different haplotypes of $N$. bombi are likely to vary in virulence, so the same may be true for $N$. ceranae. It is also possible that Higes et al.'s (2007) bees were exposed to some other agent which may have decreased their longevity synergistically with $N$. ceranae, such as pesticides or viruses. Otherwise, differences could be explained by the different susceptibility of the bees used in the experiment, although in the case of $N$. apis no differences in race susceptibility were detected in several experiments (Malone et al., 1995; Malone and Stefanovic, 1999). However, no information on genetic susceptibility is yet available for infection with N. ceranae.

Feeding colonies with thymol syrup may represent an efficient way of reducing nosema infection in the hive, as results from this experiment show that, in laboratory conditions, bees fed with thymol have lower spore loads and live longer than control bees. Indeed, if a "wellness" index is calculated as follows: proportion of survivors/spore load, measured on the last time point $(25 \mathrm{~d})$, bees fed with thymol syrup have the highest value $\left(2.4 \times 10^{-9}\right)$, followed by the group fed with resveratrol syrup $\left(1.9 \times 10^{-9}\right)$, whereas bees fed with control candy $\left(1.9 \times 10^{-10}\right)$ had a ten-fold lower value. In future experiments, it may be interesting to combine the nosema inhibiting effect of thymol and the longevity-extending effect of resveratrol. Furthermore, the results from laboratory tests need to be evaluated at the colony level.

\section{ACKNOWLEDGEMENTS}

We wish to thank Francesco Leonardi, Giovanna Marani for collaboration in experimental activities and Franco Mutinelli and Anna Granato for their assistance with molecular analysis. We also thank beekeeper Angelo Barberis for providing nosema diseased bees, Simone Franceschetti for the work in the bee yard and a kind friend for encouragement.

Effet du thymol et du resveratrol, administrés avec du sucre candi ou du sirop, sur le développement de Nosema ceranae et sur la longévité des abeilles (Apis mellifera), en conditions de laboratoire.

Nosema / thymol / resveratrol / abeille/ expérience en laboratoire

Zusammenfassung - Der Effekt von Thymol und Resveratrol, verabreicht mit Sirup oder Zuckerteig, auf die Entwicklung von Nosema ceranae und die Lebensdauer von Honigbienen Apis mellifera) unter Laborbedingungen. Der Parasit $\mathrm{No}$ sema ceranae, ursprünglich von der asiatischen Honigbiene Apis cerana stammend, ist in den letzten Jahren in Honigbienen europäischer Abstammung auf der ganzen Welt nachgewiesen worden und wird von einigen Autoren auch für den plötzlichen Zusammenbruch von Völkern verantwortlich gemacht. In einem vorhergegangenen Experiment 
untersuchten wir einige natürliche Substanzen auf ihre Wirkung auf eine Nosema-Infektion und fanden einen vielversprechenden hemmenden Effekt von Thymol und Resveratrol, die in Zuckerteig verabreicht wurden. In dieser Untersuchung verglichen wir den Effekt von Thymol (100 ppm) und Resveratrol (10 ppm) auf den Infektionsverlauf von künstlich mit $N$. ceranae infizierten Bienen in zwei verschiedenen Verabreichungsformen, Zuckerteig und Sirup.

Frisch geschlüpfte Nosema-freie Arbeiterinnen wurden individuell mit $1 \mu \mathrm{L}$ Saccharosesirup gefüttert, der 18000 N. ceranae Sporen enthielt. Die Entwicklung der Infektion wurde beobachtet, indem aus jedem Käfig zu den Beobachtungszeitpunkten an Tag 8, 13, 19 und 25 p.i. zwei lebende Bienen entnommen und seziert wurden; die Zahl der toten Bienen wurde täglich protokolliert. Die Ergebnisse der Überlebensanalyse (Abb. 1, Tab. I) zeigten, dass 12 Tage nach Beginn des Experiments in allen Gruppen noch etwa $90 \%$ der Bienen am Leben waren, unabhängig von der verabreichten aktiven Substanz oder der Verabreichungsform. Am Ende des Experiments gab es dagegen deutliche Unterschiede zwischen den Behandlungsformen, da Bienen, die mit Sirup gefüttert wurden, der Thymol oder Resveratrol enthielt, signifikant länger überlebten (Median der Überlebenszeit 23 Tage, bzw. 25 Tage) als Bienen, die Kontrollsirup erhielten (Median der Überlebenszeit 20 Tage) oder Bienen, die mit Kontroll-Zuckerteig oder Substanz-Zuckerteig gefüttert wurden.

Die Sporenbelastungen am letzten Beobachtungszeitpunkt $(25 \mathrm{~d})$ waren signifikant unterschiedlich, wobei Bienen, die mit Thymol-Sirup oder Teig gefüttert wurden, am wenigsten Sporen hatten (Tab. II). Bei Bienen, die mit Thymol gefüttert wurden, war die Entwicklung der Infektion deutlich langsamer als in den anderen Gruppen. Am Ende des Experiments traten die höchsten bzw. niedrigsten Infektionsniveaus bei Kontrollzuckerteig bzw. Thymolsirup auf $(138,33 \pm 6,74$ bzw. $60,16 \pm 9,17$ Millionen Sporen pro Biene \pm SE).

Thymol, entweder in Sirup oder in Zuckerteig verabreicht, war deutlich in der Lage, die Entwicklung von $N$. ceranae im Mitteldarm zu verzögern. Es wurde vermutet, dass Thymol die Entwicklung der Infektion durch Perforation der Plasmamembran behindert. Die von jeder Biene durchschnittlich täglich aufgenommene Dosis war 3,2 $\times 10^{-3} \mathrm{mg}$ : diese Menge erschien ausreichend, um die Entwicklung der Infektion zu verhindern. Das längere Überleben der mit Resveratrol gefütterten Bienen, in denen die Sporenbelastung sich nicht von den Kontrollbienen unterschied, könnte durch die spezifischen lebensverlängernden anti-oxidativen Eigenschaften dieser Substanz erklärt werden. In der Tat konnte gezeigt werden, dass Resveratrol die Lebensspanne einiger Invertebraten verlängern kann, indem es Enzyme aktiviert, die das Überleben von Zellen fördern. Das
Füttern von Bienenvölkern mit Thymol könnte eine effektive Maßnahme sein, um Nosema-Infektionen $\mathrm{zu}$ vermindern.

\section{Nosema / Microsporidia / Honigbiene / Thymol / Resveratrol}

\section{REFERENCES}

Bennis S., Chami F., Chami N., Bouchikhi T., Remmal A. (2004) Surface alteration of Saccharomyces cerevisiae induced by thymol and eugenol, Lett. Appl. Microbiol. 38, 454-458.

Bogdanov S., Kilchenmann V., Imdorf A., Fluri P. (1998) Residues in honey after application of thymol against varroa using the franko thymol frame, Am. Bee J. 133, 610-611.

Cantwell G.E. (1970) Standard methods for counting Nosema spores, Am. Bee J. 110, 222-223.

Chauzat M.P., Higes M., Martin-Hernandez R., Meana A., Cougoule N., Faucon J.P. (2007) Presence of Nosema ceranae in French honey bee colonies, J. Apicult. Res. 46, 127-128.

Chen Y., Evans J.D., Smith I.B., Pettis J.S. (2008) Nosema ceranae is a long-present and widespread microsporidian infection of the European honey bee (Apis mellifera) in the United States, J. Invertebr. Pathol. 97, 186-188.

Chiesa F. (1991) Effective control of varroatosis using powdered thymol, Apidologie 22, 135-145.

Dambolena J.S., Lopez A.G., Canepa M.C., Theumer M.G., Zygadlo J.A., Rubinstein H.R. (2008) Inhibitory effect of cyclic terpenes (limonene, menthol, menthone and thymol) on Fusarium verticillioides MRC 826 growth and fumonisin B1 biosynthesis, Toxicon 51, 37-44.

Dann J.M., Sykes P.H., Mason D.R., Evans J.J. (2009) Resveratrol and (-)-epigallocatechin-3gallate Reduce VEGF Secretion from Endometrial Tumour Cells, Reproductive Sciences 16, p. 151A.

Detzel A., Wink M. (1993) Attraction, deterrence or intoxication of bees (Apis mellifera) by plant allelochemicals, Chemoecology 4, 8-18.

Ebert T.A., Kevan P.G., Bishop B.L., Kevan S.D., Downer R.A. (2007) Oral toxicity of essential oils and organic acids fed to honey bees (Apis mellifera), J. Apicult. Res. 46, 220-224.

EC (2007) Council Regulation N. 834/2007 of 28 June 2007 on organic production and labelling of organic products and repealing Regulation (EEC) N. 2092/91, Official Journal of the European Union L189, 20.07.2007, pp. 1-23.

Fries I. (1993) Nosema apis - A parasite in the honey bee colony, Bee World 74, 5-19.

Fries I., Elkbohm G., Villumstad E. (1984) Nosema apis, sampling techniques and honey yield, J. Apicult. Res. 23, 102-105. 
Fries I., Feng F., daSilva A., Slemenda S.B., Pieniazek N.J. (1996) Nosema ceranae n sp (Microspora, Nosematidae), morphological and molecular characterization of a microsporidian parasite of the Asian honey bee Apis cerana (Hymenoptera, Apidae), Eur. J. Protistol. 32, 356-365.

Goodwin M., Houten A., Perry J., Blackmann R. (1990) Cost benefit analysis of using fumagillin to treat nosema, New Zeal. Beekeeper 208, 11-12.

Higes M., García-Palencia P., Martín-Hernández R., Meana A. (2007) Experimental infection of Apis mellifera honey bees with Nosema ceranae (Microsporidia), J. Invertebr. Pathol. 94, 211-217.

Higes M., Martín R., Meana A. (2006) Nosema ceranae, a new microsporidian parasite in honey bees in Europe, J. Invertebr. Pathol. 92, 93-95.

Higes M., Martin-Hernandez R., Botias C., Bailon E.G., Gonzalez-Porto A.V., Barrios L., Del Nozal M.J., Bernal J.L., Jimenez J.J., Palencia P.G., Meana A. (2008) How natural infection by Nosema ceranae causes honey bee colony collapse, Environ. Microbiol. 10, 2659-2669.

Higes M., Martin-Hernandez R., Garrido-Bailón E., Gonzalez-Porto A.V., Garcìa-Palencia P., Meana A., Del Nozal M.J., Mayo R., Bernal J.L. (2009) Honey bee colony collapse due to Nosema ceranae in professional apiaries, Environ. Microbiol. Rep. 1, 110-113.

Howitz K.T., Bitterman K.J., Cohen H.Y., Lamming D.W., Lavu S., Wood J.G., Zipkin R.E., Chung P., Kisielewski A., Zhang L.L., Scherer B., Sinclair D.A. (2003) Small molecule activators of sirtuins extend Saccharomyces cerevisiae lifespan, Nature 425, 191-196.

Huang W.F., Bocquet M., Lee K.C., Sung I.H., Jiang J.H., Chen Y.W., Wang C.H. (2008) The comparison of rDNA spacer regions of Nosema ceranae isolates from different hosts and locations, J. Invertebr. Pathol. 97, 9-13.

Imdorf A., Kilchenmann V., Bogdanov S., Bachofen B., Beretta C. (1995) Toxic effects of thymol, camphor, menthol and eucalyptol on Varroa jacobsoni Oud and Apis mellifera L in a laboratory test, Apidologie 26, 27-31.

Juven B.J., Kanner J., Schved F., Weisslowicz H. (1994) Factors that interact with the antibacterial action of thyme essential oil and its active constituents, J. Appl. Bacteriol. 76, 626-631.

Katznelson H., Jamieson H. (1952) Control of nosema disease with fumagillin, Science 115, 70-71.

Klee J., Besana A.M., Genersch E., Gisder S., Nanetti A., Tam D.Q., Chinh T.X., Puerta F., Ruz J.M., Kryger P., Message D., Hatjina F., Korpela S., Fries I., Paxton R.J. (2007) Widespread dispersal of the microsporidian Nosema ceranae, an emergent pathogen of the western honey bee, Apis mellifera, J. Invertebr. Pathol. 96, 1-10.

Leiro J., Cano E., Ubeira F.M., Orallo F., Sanmartìn M.L. (2004) In vitro effects of resveratrol on the viability and infectivity of the Microsporidian
Encephalitozoon cuniculi, Antimicrob. Agents Ch. 48, 2497-2501.

Lenga R.E. (1988) The Sigma-Aldrich library of chemical safety data, Sigma-Aldrich Corporation 35.

Liu T.P. (1973) Effects of Fumidil B on the spore of Nosema apis and on lipids of the host cell as revealed by freeze-etching, J. Invertebr. Pathol. 22, 364-368.

Luna C., Li G.R., Liton P.B., Qiu J.M., Epstein R.L., Challa P., Gonzalez P. (2009) Resveratrol prevents the expression of glaucoma markers induced by chronic oxidative stress in trabecular meshwork cells, Food Chem. Toxicol. 47, 198-204.

MacDonald D.N. (1978) Diseases of the honey bee, Apis mellifera (Hymeoptera: Apidae) in British Colombia, with special emphasis on nosema disease, Nosema apis (Sporozoa: Nosematidae), in the lower Fraser Valley, 13. Simon Fraser University, Canada.

Mahmoud A.L.E. (1999) Inhibition of growth and aflatoxin biosynthesis of Aspergillus flavus by extracts of some Egyptian plants, L., Appl. Microbiol. 29, 334-336.

Maistrello L., Lodesani M., Costa C., Leonardi F., Marani G., Caldon M., Mutinelli F., Granato A. (2008) Screening of natural compounds for the control of nosema disease in honey bees (Apis mellifera), Apidologie 39, 436-445.

Malone L.A., Stefanovic D. (1999) Comparison of the responses of two races of honey bees to infection with Nosema apis Zander, Apidologie 30, 375382.

Malone L.A., Giacon H.A., Newton M.R. (1995) Comparison of the responses of some New Zealand and Australian honey bees (Apis mellifera L) to Nosema apis Z, Apidologie 26, 495-502.

Martin P. (2003) Veterinary drug residues in honey, Apiacta 38, 21-23.

Martìn-Hernández R., Meana A., Prieto L., Martìnez Salvador A., Garrido-Bailón E., Higes M. (2007) Outcome of colonization of Apis mellifera by Nosema ceranae, Appl. Environ. Microb. 73, 6331-6338.

Matheson A. (1996) World bee health update, Bee World 77, 45-51.

Mayack C., Naug D. (2009) Energetic stress in the honey bee Apis mellifera from Nosema ceranae infection, J. Invertebr. Pathol. 100, 185-188.

Moffet J.O., Lackett J.J., Hitchcock J.D. (1969) Compounds tested for control of nosema in honey bees, J. Econ. Entomol. 62, 886-889.

Naug D., Gibbs A. (2009) Behavioral changes mediated by hunger in honey bees infected with Nosema ceranae, Apidologie, DOI: 10.1051/apido/2009039.

Pallas M., Casadesus G., Smith M.A., Coto-Montes A., Pelegri C., Vilaplana J., Camins A. (2009) Resveratrol and Neurodegenerative Diseases: Activation of SIRT1 as the Potential Pathway towards Neuroprotection, Curr. Neurovasc. Res. 6, 70-81. 
Park J.S., Kim K.M., Kim M.H., Chang H.J., Baek M.K., Kim S.M., Do Jung Y. (2009) Resveratrol Inhibits Tumor Cell Adhesion to Endothelial Cells by Blocking ICAM-1 Expression, Anticancer Res. 29, 355-362.

Paxton R.J., Klee J., Korpela S., Fries I. (2007) Nosema ceranae has infected Apis mellifera in Europe since at least 1998 and may be more virulent than Nosema apis, Apidologie 38, 558-565.

Rice R.N. (2001) Nosema disease in honey bees. Genetic variation and control. Report n. 01/46, Australian Government, Rural Industries Research and Development Corporation.

Shapiro S., Guggenheim B. (1995) The action of thymol on oral bacteria, Oral Microbiol. Immunol. 10, 241-246.

Svircev A.M., Smith R.J., Zhou T., Hernadez M., Liu W., Chu C.L. (2007) Effects of thymol fumigation on survival and ultrastracture of Monilinia fructicola, Postharvest Biol. Tech. 45, 228-233.

Szabo T.I., Heikel D.T. (1987) Effect of dry fumagillin feeding on spring Nosema spore counts in overwintered colonies, Am. Bee J. 127, 210-211.

Tay W.T., O’Mahony E., Paxton, R.J. (2005) Complete rRNA gene sequences reveal that the Microsporidium Nosema bombi infects diverse bumble bee (Bombus spp.) hosts, yet contains multiple polymorphic sites, J. Eukaryot. Microbiol. 52, 505-513.
Valenzano D.R., Terzibasi E., Genade T., Cattaneo A., Domenici L., Cellerino A. (2006) Resveratrol prolongs lifespan and retards the onset of age-related markers in a short-lived vertebrate, Curr. Biol. 16, 296-300.

Viollon C., Chaumont J.P. (1994) Antifungal properties of essential oils e their main components upon Cryptococcus neoformans, Mycopathologia 123, 151-153.

Williams G.R., Sampson M.A., Shutler D., Rogers R.E.L. (2008a) Does fumagillin control the recently detected invasive parasite Nosema ceranae in western honey bees (Apis mellifera)? J. Invertebr. Pathol. 99, 342-344.

Williams G.R., Shafer A.B.A., Rogers R.E.L., Shutler D., Stewart D.T. (2008b) First detection of Nosema ceranae, a microsporidian parasite of European honey bees (Apis mellifera), in Canada and central USA, J. Invertebr. Pathol. 97, 189-192.

Wood J.G., Rogina B., Lavu S., Howitz K., Helfand S.L., Tatar M., Sinclair D. (2004) Sirtuin activators mimic caloric restriction and delay ageing in metazoans, Nature 431, 107.

Wyborn M.H., McCutcheon D.M. (1987) A comparison of dry and wet fumagillin treatments for spring nosema disease suppression of overwintered colonies, Am. Bee J. 127, 207-209. 